\title{
ASSESSMENT OF THE IMPACTS OF BUILDING CONSTRUCTION ACTIVITIES ON THE ENVIRONMENT
}

\author{
F. O. Akintayo ${ }^{1, *}$, O. N. Oyebade ${ }^{2}$, S. P. Songca ${ }^{3}$, N. O. Adebisi ${ }^{4}$, O. S. Oluwafemi ${ }^{5}$ \\ and 0. O. Fadipe 6 \\ 1, 2, Department of Civil Engineering, University of IbADAN, IBADAN OYo StaTE, NIGERIA. \\ 3, DEPARTMENT OF CHEMISTRY, UNIVERSITY OF ZULULAND, ZULULAND, KWAZULU-NATAL, SOUTH AFRICA. \\ 4, DePARTMENT OF EARTH SCIENCES, Olabisi ONABAANJO UnIVERSITY, Ago-IWOYE, OgUn STATE, NIGERIA. \\ 5, DePARTMENT OF APPLIED ChEMISTRY, UNIVERSITY OF JOHANNESBURG, JOHANNESBURG, SOUTH AFRICA. \\ 6, Department of Civil Engineering, Osun State University, Osogbo, Osun State, NIGERIA.
}

E-mail addresses: ${ }^{1}$ fo.akintayo@ui.edu.ng, ${ }^{2}$ lekan1980@yahoo.com, ${ }^{3}$ songcas@unizulu.ac.za
${ }^{4}$ adebisi.niyi@oouagoiwoye.edu.ng, ${ }^{5}$ matoem@cput.ac.za, ${ }^{6}$ olusola.fadipe@uniosun.edu.ng

\begin{abstract}
Activities in building construction industry contribute to air pollution. In this study, gas data from four locations at each three building construction sites in Doha, Qatar were collected and analyzed. Questionnaires were also administered to companies that are involved in building construction projects. The results showed traces of $\mathrm{SO}_{2}, \mathrm{CO}_{2}, \mathrm{CO}$ and $\mathrm{NO}_{2}$ but in amounts below the detrimental limit stipulated by the Ministry of Environment, Qatar. Questionnaire responses revealed that the extraction of raw materials and the energy consumed during construction occur quite often, but strongly implicated dust generated from construction sites and waste disposal, as major factors causing air pollution in the area. It is therefore, recommended that regular monitoring of air should be carried out within building construction sites to aid detection of air contamination. This will serve as a control measure to stimulate catalytic conversion of exhaust, reuse and recycling of waste materials.
\end{abstract}

Keywords: Air pollution, Building construction activities, Dust, Emissions and Environment.

\section{INTRODUCTION}

Building construction enhances growth and development of a country, thereby providing shelter, the second necessity of life for both the citizens and non-citizens [1]. The processes of the building construction result in various environmental impacts [2-4]. Many of the environmental issues are caused by the dust and noise generated, raw materials used, and energy consumed during the construction process. [5] Noted that the design, construction, maintenance and use of structures have direct and indirect impacts on the environment, which include energy impact, ecological impact, visual impact and material impact. The identification of likely impacts on the environment in order of severity is a task that needs to be accomplished for minimising the effect of construction projects on the environment [6]. Environmentally harmful activities differ from one industry to another, but it is well known that the biggest contributor to greenhouse gas emissions is the built environment [7]. The cumulative environmental impacts generated by the building during its whole life-cycle, can be of the same order of magnitude as those generated during the construction stage [8]. The construction sector is responsible for a high percentage of the environmental impacts produced by the developed countries. It has been discovered that the materials and energy used during the construction process have effect on the environment [9]. This study will report on the gases emitted during building construction, identify the different environmental impacts of building construction projects, identify building construction

* Corresponding author, tel: +234-803-831-0210 
factors that have negative environmental impacts and identify methods to control and prevent the negative environmental impacts of building construction. The aim of the study is to assess the impacts of building construction on the environment in Doha, Qatar and the objectives of the study are: to carry out preliminary survey of selected building construction sites in the study area, to assess the impacts of building construction projects on the environment in the study area, to collect and analyse the sample gases that are emitted from building construction sites and to develop mechanism to control the impacts of building construction on the environment.

\section{MATERIALS AND METHODS}

\subsection{Gas Data Collection with Wolf Pack Area Monitor:}

Gas data were collected by applying two different methods: the use of Wolf pack area monitor to identify the gasses that are emitted from the building construction sites to the environment and the use of a structured questionnaire for the Environmental Impacts Assessment (EIA) within the construction companies that handled building projects.

\subsection{Data Collection}

The Wolf Pack Area Monitor was employed to capture the readings of $\mathrm{CO}_{2}, \mathrm{CO}, \mathrm{NO}_{2}, \mathrm{SO}_{2}$ and temperature readings at four different locations in each of the three construction sites A, B and C selected for the study, at intervals of 1 hour at the peak of daily construction activities for seven working days. The readings were taken at four locations from each of the construction companies (Ismail Bin Ali, HKH Construction Company and Construction and Reconstruction Company sites) shown in Table 1, 2 and 3. Gaseous emissions to the atmosphere may be generated during construction. Emissions to air may be gaseous or in the form of particles loaded with adsorbed gases. The data were extracted from the instrument to a laptop using wolf sense PC software.

\subsection{Data Collection with Structured Questionnaire:}

A link to administer the structured questionnaire on environmental impact assessment was created by signing up with www.surveymonkey.com. The link was forwarded to email addresses of the randomly selected 50 building construction companies retrieved from Qatar online directory. Thirty-eight (38) responses were received in the account created in survey monkey through the link. Four out (4) the respondents were diploma holder, twenty-six (26) respondents were bachelor's degree holder and eight (8) respondents were post graduate degree holder. Sixteen (16) respondents of the total numbers of respondents have been practicing in the construction industry within 15years and 6-10years, four (4) of the respondents have been practising within 11-15years and two (2) of the respondents have been practicing within 1620years.

\subsection{Analysis of Data}

The data readings of $\mathrm{CO}_{2}, \mathrm{CO}, \mathrm{NO}_{2}, \mathrm{SO}_{2}$ and temperature were collected from four locations of the three different sites. The data were analysed to determine if the concentration of the gases is suitable to the human environment by comparing to the Ministry of Environment and World Health Organization standards. The responses retrieved from the administered questionnaires were also analysed using descriptive tools (frequency, percentage and mean item score (MIS)) from www.surveymonkey.com shown below. These tools were very useful in conveying a quick expression of any clustering variations and possible trends in the values of the variables. The mean item score in equation below 1 is calculated to obtain the mean of factors during the use of Likert scale of measurement.

Mean item score (MIS) $=\frac{\left(5 n_{5}+4 n_{4}+3 n_{3}+2 n_{2}+n_{1}\right)}{5\left(n_{5}+n_{4}+n_{3}+n_{2}+n_{1}\right)}$

$\mathrm{n}_{1}=$ number of respondents who answered never or strongly disagree

$\mathrm{n}_{2}=$ number of respondents who answered rarely or disagree

$\mathrm{n}_{3}=$ number of respondents who answered often or neutral

$\mathrm{n}_{4}=$ number of respondents who answered most often or agree

$\mathrm{n}_{5}=$ number of respondents who answered very often or strongly agree

\section{RESULTS AND DISCUSSION}

\subsection{Analysis of Emitted Gas from Construction Sites}

The Wolf Pack Area Monitor was able to measure the concentration of $\mathrm{CO}_{2}, \mathrm{CO}, \mathrm{NO}_{2}$, traces of $\mathrm{SO}_{2}$ gases and temperature. The typical gaseous emissions to air from construction sites include nitrogen oxides ( $\mathrm{NO}$ and $\left.\mathrm{NO}_{2}\right)$, sulphur dioxide $\left(\mathrm{SO}_{2}\right)$, carbon dioxide $\left(\mathrm{CO}_{2}\right)$ and Carbon monoxide (CO) [10]. The mean of the concentration of gases for four locations of each site 
were calculated. $\mathrm{HKH}$ Construction Company has the maximum $\mathrm{CO}_{2}$ concentration of $804.0 \mathrm{mg} / \mathrm{m}^{3}$ (Figure 1) followed by CRC with $790.5 \mathrm{mg} / \mathrm{m}^{3}$ while Ismail Bin Ali has the minimum concentration of $782.3 \mathrm{mg} / \mathrm{m}^{3}$. The maximum CO concentrated $\left(3.2 \mathrm{mg} / \mathrm{m}^{3}\right)$ is recorded at the Construction and Reconstruction Company followed by HKH Construction Company with $2.8 \mathrm{mg} / \mathrm{m}^{3}$ and Ismail Bin Ali has the minimum with $2.5 \mathrm{mg} / \mathrm{m}^{3}$ (Figure 2). The maximum $\mathrm{NO}_{2}$ concentration $\left(40.0 \mu \mathrm{g} / \mathrm{m}^{3}\right)$ was also reported at Construction and Reconstruction Company followed by $\mathrm{HKH}$ Construction Company with $21.3 \mu \mathrm{g} / \mathrm{m}^{3}$ and Ismail Bin Ali has the minimum with $9.3 \mu \mathrm{g} / \mathrm{m}^{3}$ (Figure 3) and for $\mathrm{SO}_{2}$, no data were recorded. The maximum concentration of $\mathrm{CO}$ detected was $3.2 \mathrm{mg} / \mathrm{m}^{3}$; however, this is lower than the $40 \mathrm{mg} / \mathrm{m}^{3}$ stipulated by the Ministry of Environment of Qatar (MOE) and $35 \mathrm{mg} / \mathrm{m}^{3}$ stipulated by the World Health Organization (WHO). The level of $\mathrm{CO}$ measured is still within the safe limit, but site workers and site visitors are however, exposed to health hazards produced by hypoxia due to the binding of carbon monoxide to haemoglobin, which reduces the oxygen carrying capacity of the blood and decreases the dissociation of oxygen into extravascular tissue [11]. Gaseous $\mathrm{CO}$ is a slow poison that kills by reducing the oxygen supply in the body [12]. [13]
Stated that exposure to a concentration of $20 \mathrm{ppm}$ of carbon monoxide for eight hours will result in a carboxyl haemoglobin level of about $2.8 \%$. The maximum concentration of $\mathrm{CO}_{2}$ was $804 \mathrm{mg} / \mathrm{m}^{3}$. This is less than the stipulated maximum of $10,000 \mathrm{ppm}$ $\left(18,000.090 \mathrm{mg} / \mathrm{m}^{3}\right) . \mathrm{A} \mathrm{CO}_{2}$ concentration of 2500 to $5000 \mathrm{ppm}$ could cause headache, indicating that concentration of $\mathrm{CO}_{2}$ within the study area is not high enough to cause health hazard [12]. The maximum concentration of $\mathrm{NO}_{2}$ detected was $40.0 \mu \mathrm{g} / \mathrm{m}^{3}$. However, this is lower than the $400 \mu \mathrm{g} / \mathrm{m}^{3}$ stipulated by the Ministry of Environment of Qatar and $200 \mu \mathrm{g} / \mathrm{m}^{3}$ stipulated by the World Health Organization. The level of $\mathrm{NO}_{2}$ measured is still within the safe limit. The main health outcomes of interest of nitrogen dioxide are respiratory symptoms, bronchi-constriction, increased bronchial reactivity, airway inflammation, and decreases in immune defence leading to increased susceptibility to respiratory infection [11]. Gaseous emissions may reduce air quality with impacts on human health, particularly where emissions are of harmful gases. The impact can be extremely serious, where emissions contain harmful compounds such as dioxins [10].

Table 1: Gas concentrations at Ismail Bin Ali

\begin{tabular}{lllll}
\hline $\mathrm{S} / \mathrm{N}$ & $\mathrm{NO}_{2}\left(\mu \mathrm{g} / \mathrm{m}^{3}\right)$ & $\mathrm{CO}\left(\mathrm{mg} / \mathrm{m}^{3}\right)$ & $\mathrm{CO}_{2}\left(\mathrm{mg} / \mathrm{m}^{3}\right)$ & $\mathrm{TEMP}^{\circ} \mathrm{C}$ \\
\hline 1 & 0.0 & 1.0 & 768.3 & 34.6 \\
2 & 0.0 & 1.3 & 782.0 & 34.8 \\
3 & 0.0 & 4.5 & 786.0 & 35.1 \\
4 & 37.1 & 3.1 & 792.7 & 36.2 \\
Mean & 9.3 & 2.5 & 782.3 & 35.2 \\
\hline
\end{tabular}

Table 2: Gas concentrations at Construction and Reconstruction Company

\begin{tabular}{lllll}
\hline $\mathrm{S} / \mathrm{N}$ & $\mathrm{NO}_{2}\left(\mu \mathrm{g} / \mathrm{m}^{3}\right)$ & $\mathrm{CO}\left(\mathrm{mg} / \mathrm{m}^{3}\right)$ & $\mathrm{CO}_{2}\left(\mathrm{mg} / \mathrm{m}^{3}\right)$ & $\mathrm{TEMP}{ }^{\circ} \mathrm{C}$ \\
\hline 1 & 99.0 & 2.2 & 779.0 & 36.0 \\
2 & 60.9 & 2.5 & 786.0 & 36.4 \\
3 & 0.0 & 3.8 & 799.0 & 36.5 \\
4 & 0.0 & 4.4 & 798.7 & 36.2 \\
Mean & 40.0 & 3.2 & 790.5 & 36.3 \\
\hline
\end{tabular}

Table 3: Gas concentrations at HKH Construction Company

\begin{tabular}{lllll}
\hline $\mathrm{S} / \mathrm{N}$ & $\mathrm{NO}_{2}\left(\mu \mathrm{g} / \mathrm{m}^{3}\right)$ & $\mathrm{CO}\left(\mathrm{mg} / \mathrm{m}^{3}\right)$ & $\mathrm{CO}_{2}\left(\mathrm{mg} / \mathrm{m}^{3}\right)$ & $\mathrm{TEMP}{ }^{\circ} \mathrm{C}$ \\
\hline 1 & 0.0 & 1.5 & 783.0 & 31.3 \\
2 & 0.0 & 1.7 & 793.0 & 31.7 \\
3 & 85.3 & 3.7 & 830.0 & 33.9 \\
4 & 0.0 & 4.3 & 810.0 & 35.6 \\
Mean & 21.3 & 2.8 & 804.0 & 33.1 \\
\hline
\end{tabular}




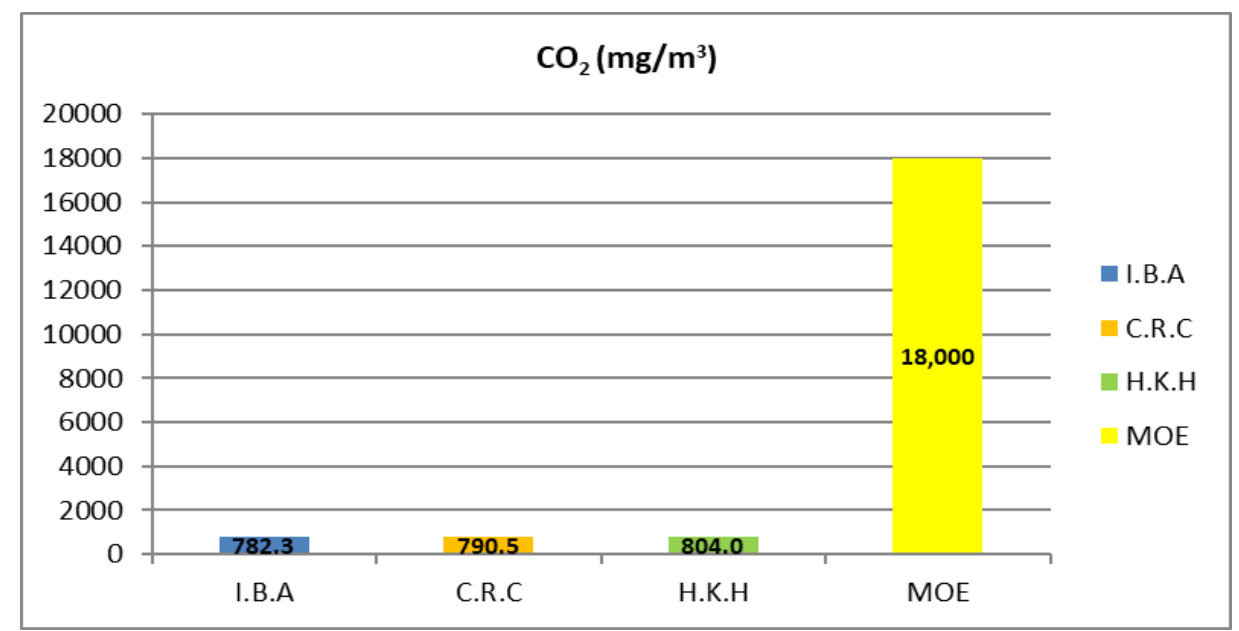

Figure 1: Average concentration of $\mathrm{CO}_{2}$ for each site

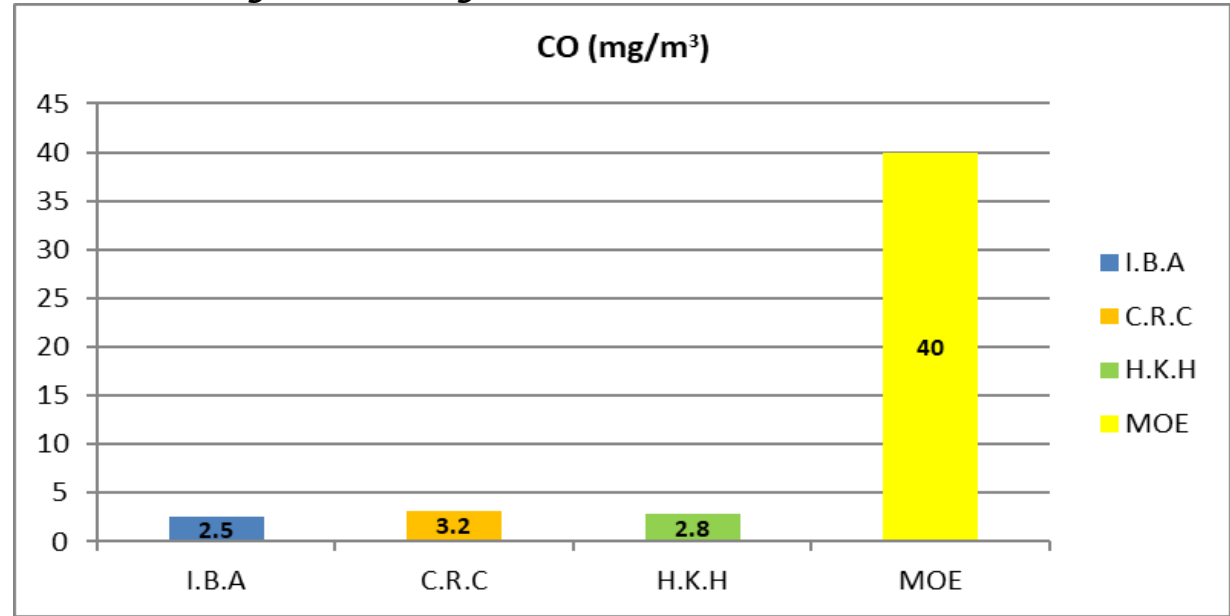

Figure 2: Average concentration of $\mathrm{CO}$ for each site

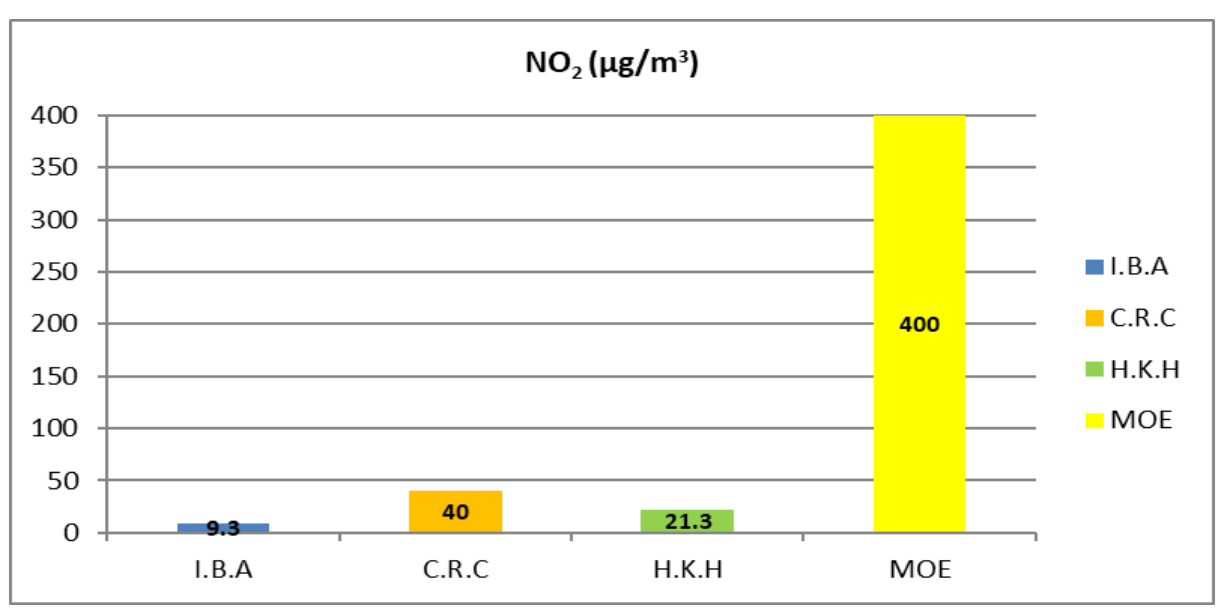

Figure 3: Average concentration of $\mathrm{NO}_{2}$ for each site

\subsection{Environmental Impact of Building Construction Projects}

The result of the environmental impacts of building construction is shown in Figure 4. The result indicate that, out of the 13 environmental impacts listed in the questionnaire, the respondents strongly agree that consumption of energy which was ranked first with M.I.S 0.82 occurred most often in building construction projects. Respondents agreed that extraction of materials, increase in transport need, noise pollution, emission of greenhouse gases, waste generation, land use change, increase in population, air pollution, health risk on work site, wastewater generation and increase in temperature occur most often in building construction projects with M.I.S 0.79 - 0.63 . The respondents responded neutrally to 
aesthetic degradation as part of environmental impact that often occurs in building construction. In Building construction, energy consumption happens to be the major environmental impact that occurs most often, and this is due to the use of heavy equipment and generators that burn fossil fuel to operate on site. Building projects generate significant impacts on the environment during construction. These impacts come from the energy consumed and materials used for the construction [14]. The energy consumed during the building construction also generates environmental impacts. The impacts related to the energy consumed are usually higher than impacts generated by the building materials.

\subsection{Methods of Controlling Environmental Impact}

The major sources generating the emitted gas on construction sites are the operating vehicles and machinery used on building construction sites. In order to reduce the emitted gases on construction sites, there should be proper maintenance and tuning of the engines of the machinery and vehicles used on construction sites. Catalytic converters and particulate matter filters should be used for the vehicles and machinery. The catalytic converter is installed onto the exhaust pipes of the engines of the vehicles and machineries that are used on site. It is composed of a metal housing that has a ceramic honeycomb -type interior with insulating layers. This honeycomb interior has thin wall channels that are coated with aluminium oxide support, containing platinum, rhodium, and palladium as the catalysts. The converter therefore converts toxic fumes into gases that are not nearly as harmful to the environment. The last part of the converter is a control system that controls the fuel -injection system. This system is aided by an oxygen sensor that monitors how much oxygen is in the exhaust stream. The three-way catalytic converter (Figure 5) reduces nitrogen oxides into elemental nitrogen and oxygen, oxidises carbon monoxide to carbon dioxide and oxidises hydrocarbons into carbon dioxide and water.

The various methods of controlling environmental impacts in building construction projects are presented in Figure 6. The respondents strongly agreed that upgrading skills and work site health and safety on vehicles to comply to set emission standards, reuse and recycling of waste materials, innovation in regard to materials technologies and methods, covering of loads entering and leaving the site, use of water as dust suppressant where applicable and putting in place real time dust monitors across sites with M.I.S 0.86 to 0.80 . Respondents agreed that improving energy efficiency in buildings, reducing material wastage in construction, increasing structure service life, minimizing dust generating activities, identification of authorized responsible person on site for air quality, elimination of site run off of water and mud and increasing of waste recycling of building materials were methods of controlling environmental impacts from construction projects, with M.I.S 0.79 to 0.74 .

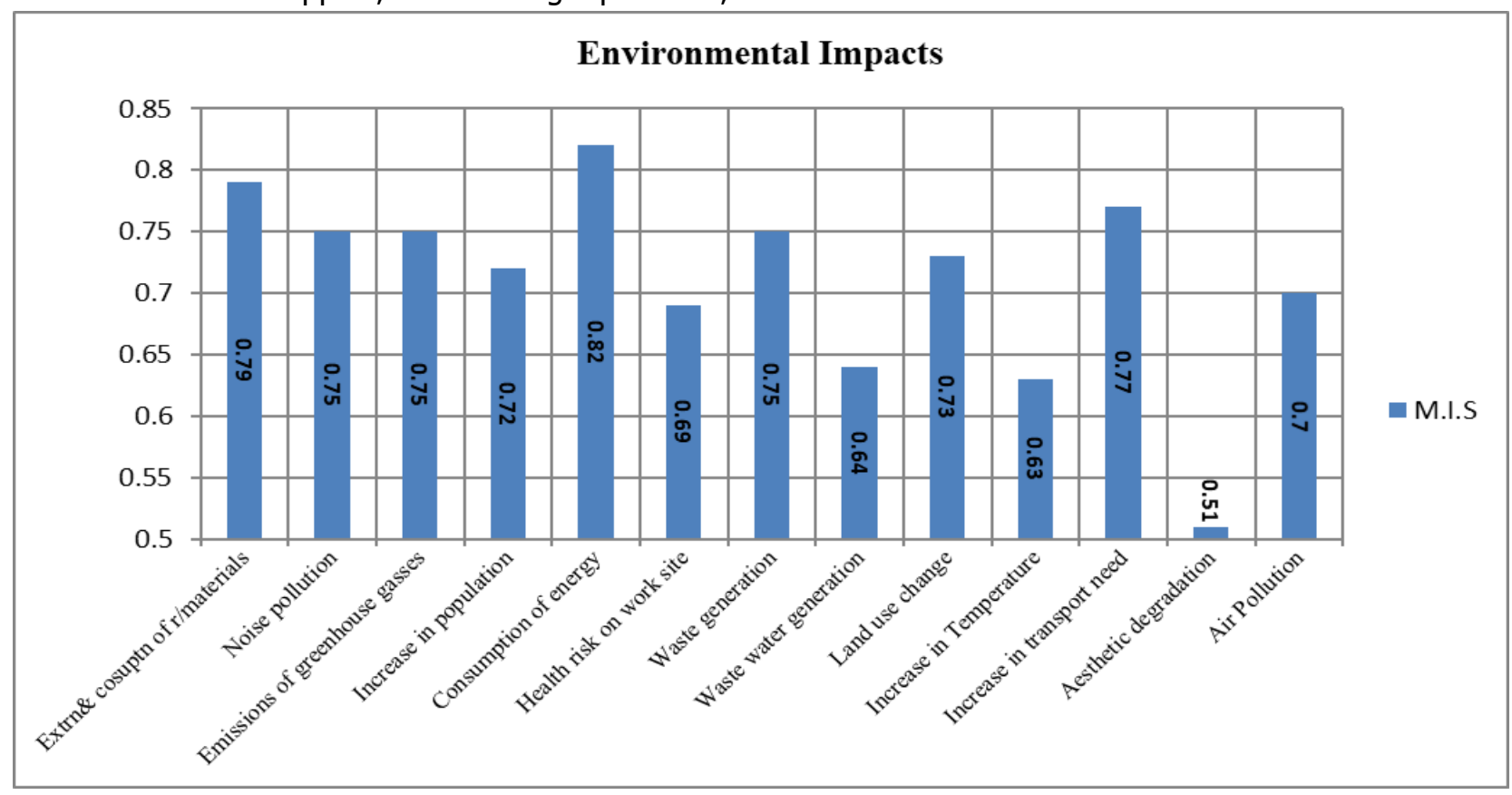

Figure 4: Assessment of environmental impact of building construction projects 


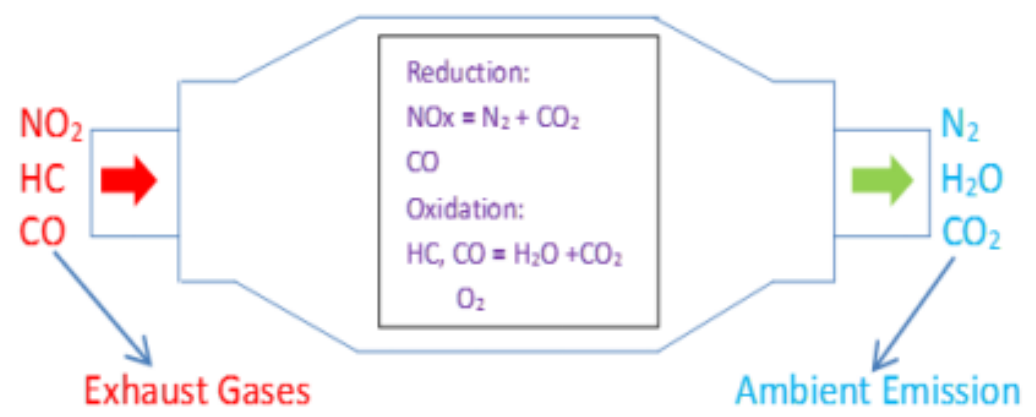

Figure 5: Three-way catalytic converter

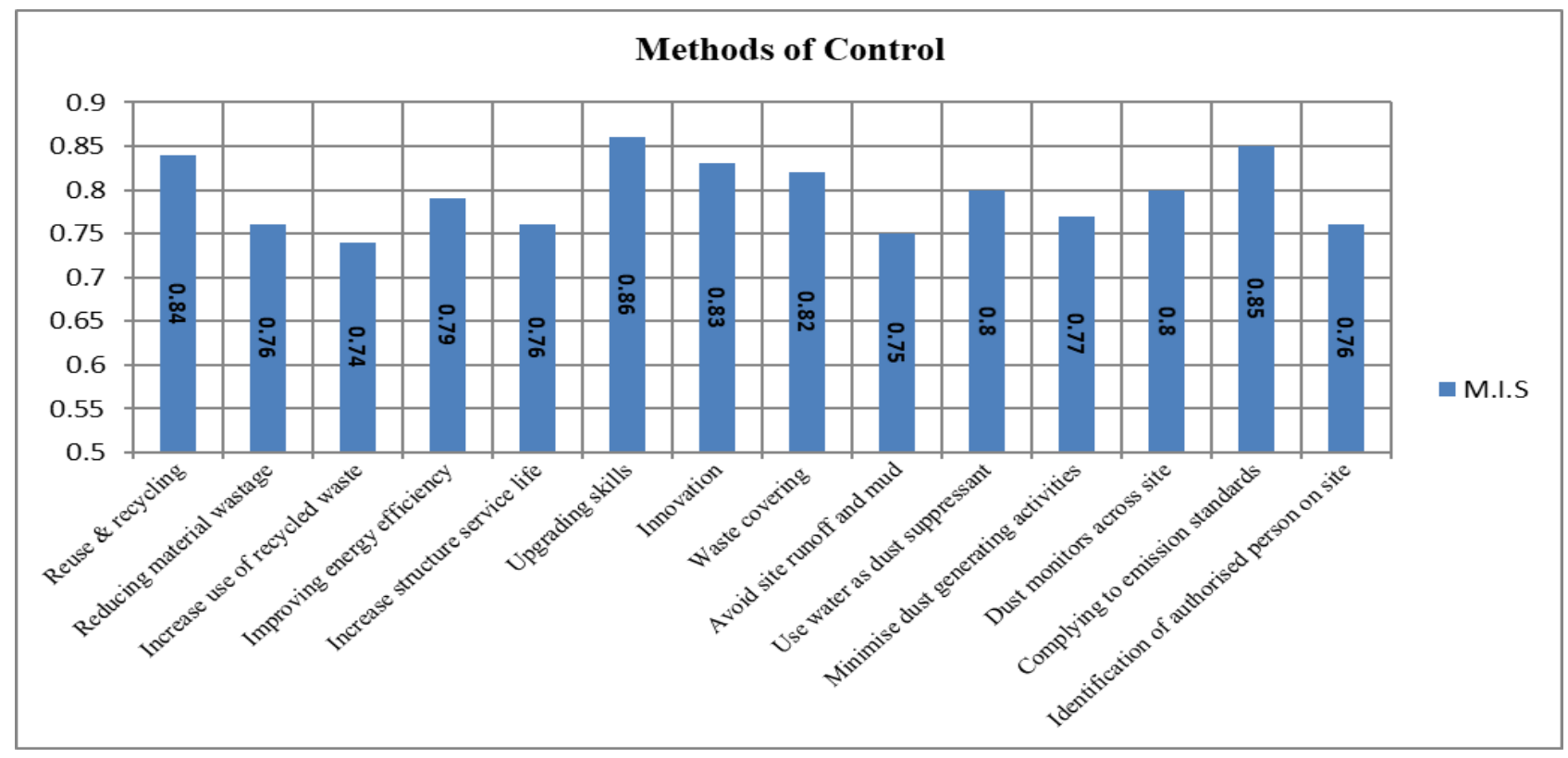

Figure 6: Methods of controlling environmental impact of building construction project

The resource efficiency of building materials would be increased if there were measures put in place to reduce waste in the manufacturing processes. These measures include recycling of material to create new products to reduce construction waste. Recycling of material means that the embodied energy can be preserved, improving sustainability and optimising waste management [6]. Waste generation can be reduced by recycling collected particulate matter, reusing maintenance and laboratory waste as fuel and raw material substitutes [10].

\section{CONCLUSION}

The study has revealed that gases are emitted within the construction site and the emitted gases could be harmful to the workers. The sources of the emitted gases on construction sites are from the diesel or petrol engines of vehicles and heavy construction machineries. The result showed that $\mathrm{CO}_{2}, \mathrm{CO}$ and $\mathrm{NO}_{2}$ concentrations at the Ismail Bin Ali, H.K.H
Construction Company and the Construction and Reconstruction Company sites are below the limits stipulated by the Ministry of Environment, Qatar and the World Earth Organization. The recommended method to control gases emitted from the vehicles and machineries used on site is the installation of catalytic converters. The catalytic converter is installed to the exhaust pipes of the engines of the vehicles and machineries to reduce the nitrogen oxides into elemental nitrogen and oxygen, to oxidise carbon monoxide to carbon dioxide and to oxidise hydrocarbons into carbon dioxide and water. The information retrieved from the environmental impact assessment questionnaire has revealed that extraction of raw materials and energy consumed during construction are believed to occur most often and respondents strongly agreed that dust generated from construction site and waste disposal are the major factors that cause hazard in the environment. Respondents strongly agreed that the 
methods of controlling the environmental impact include upgrading skills and work site health and safety on vehicles to comply to set emission standards, reuse and recycling of waste materials, innovation in regard to materials technologies and methods, covering of loads entering and leaving the site, use of water as dust suppressant where applicable and putting in place real time dust monitors across sites.

\section{REFERENCES}

[1] Ahmed, R. "Construction and the environment" Control Directorate, Public Commission for the Protection of Marine Resources, Environment and Wildlife, Kingdom of Bahrain, 2012.

[2] Amit, B. D. and Ipshita, S. "Environmental Impact Assessment (EIA) and Construction" International Research Journal of Environment Sciences Vol. 3(1), 2014, 58-61.

[3] Vivek K. T., Anjali V., Akash K. and Manjul G. "A review on Environmental Impact Assessment of Construction Projects" Journal of Environmental Science, Toxicology and Food Technology Vol 10(1), 2016, 21-25.

[4] Aremu, A. S., Aremu, A.O. and Olukanni D. O. "Assessment of Noise Pollution from Sawmill Activities in Ilorin, Nigeria." Nigerian Journal of Engineering Technology Vol 34(1), 2015, 72-79.

[5] Selvakumar, S. and Jaykumar, R. K. C. "Environmental impact assessment for building projects" Proceeding of International Conference on Energy, Environment and Engineering, At CIT, Coimbatore, 2016.

[6] Ijigah, E.A., Jimoh, R.A., Aruleba, B.O., and Ade, A.B. "An assessment of environmental impacts of building construction projects" www.iiste.org Accessed on May 10, 2016.

[7] United Nations Environment Programme Buildings and Climate Change "Summary for DecisionMakers" UNEP DTIE, Sustainable Consumption and Production Branch, 2009.

[8] Deng, X., Hu, Y., Deng Y. and Mahadev, S. "An Environmental impact assessment based on the numbers" Expert Systems with Applications, pp. 635-643, 2014.

[9] Patel, A. "Criteria based decision support system for Environmental clearance in Amreli and Junagarh districts using Geo-informatics" International Journal of Engineering research and technology, 2014, 1434-1438.

[10] Egyptian Environmental Affairs Agency. Environmental impact assessment guidelines for cement manufacturing plants. Arab Republic of Egypt, 2005.

[11] World Health Organization. "Guidelines for indoor air quality, selected pollutants" The WHO European Centre for Environment and Health, Denmark, 2010.

[12] Nwoke, P.N and Jimoh, O.D. Impact of traffic emission on air quality in a developing city of Nigeria. Department of Civil Engineering, Federal University of Technology Minna, Nigeria, 2005.

[13] Otti, V. I., Nwajuaku A.I., and Ejikeme R.I. "The effects of environmental air pollution in Nigeria" International Journal of Mechanical, Automobile and Production Engineering, 1, 2011, 36-42.

[14] Favre, D. and Citherlet, S. Evaluation of environmental impacts of buildings. Eleventh international IBPSA conference, Glasgow, Scotland, 2009. 